\title{
PENURUNAN KADAR FORMALIN PADA TAHU PUTIH MENGGGUNAKAN LARUTAN TEMU KUNCI DENGAN METODE TITRASI ASAM BASA
}

\author{
Erna Agung Rakhmawati ${ }^{1}$, Surti Lestari ${ }^{2}$, Linda Widyaningsih ${ }^{3}$ \\ Akafarma Sunan Giri Ponorogo, Jl. Batoro Katong 32 Ponorogo \\ Email: rakhmawati153@gmail.com, lestarisurti31@gmail.com,widyaningsihlinda85@gmail.com
}

\begin{abstract}
ABSTRAK
Latar belakang: tahu merupakan salah satu makanan yang banyak dikonsumsi masyarakat untuk mengantikan kebutuhan protein hewani. Tahu sendiri termasuk salah satu hasil oalah kedelai yang memiliki masa simpan kurang dari 3 hari dalam suhu kamar. Sehingga beberapa produsen menambahkan pengawet untuk memperpanjang masa simpan tahu. Salah satunya yaitu menggunakan pengawet formalin, formalin sendiri penggunaanya dilarang dalam makanan. Kandungan senyawa saponin dalam temu kunci mampu mereduksi formalin pada tahu putih. Sehingga pada penelitian ini menggunakan temu kunci untuk menurunkan kadar formalin. Tujuan: untuk mengetahui penurunan kadar formalin pada sampel tahu putih dengan menggunakan larutan temu kunci dengan variasi konsentrasi dan perendaman selama 90 menit. Metode: Populasi dalam penelitian ini yaitu sampel tahu putih yang didapat di salah satu pabrik tahu di Wilayah Ponorogo. Sampel dalam penelitian ini yaitu sampel tahu putih sebanyak 10 potong. Metode yang digunakan dalam penelitian ini yaitu titrasi asam basa dengan dilanjutkan analisa statistik menggunakan program SPSS. Penelitian dilakukan di Laboratorium AKAFARMA Sunan Giri Ponorogo. Hasil: hasil penelitian ini yaitu didapat kadar formalin awal pada tahu sebesar 0,0146\% dengan penurunan kadar formalin tertinggi pada konsentrasi $60 \%$ sebanyak $28,0 \%$. Simpulan dan saran: hasil analisa didapat hasil bahwa larutan temu kunci dapat menurunkan kadar formalin pada sampel tahu putih. Diharapkan untuk penelitian selanjutnya menggunakan metode yang lebih representatif.
\end{abstract}

Kata Kunci : Tahu, Formalin, Temu Kunci, Titrasi

\begin{abstract}
Background: Tofu is a food that is widely consumed by people to replace the need for animal protein. Tofu itself is one of the products of soybean which has a shelf life of less than 3 days at room temperature. So that some manufacturers add preservatives to extend the shelf life of the tofu. One of them is using formaldehyde as preservative, formalin itself is prohibited in food. The content of saponin compounds in key meeting is able to reduce formaldehyde in white tofu. So that in this study using key analysis to reduce levels of formaldehyde. Purpose: to determine the reduction in formalin levels in white tofu samples using a solution of temu Kunci with various concentrations and immersion for 90 minutes. Methods: The population in this study is a sample of white tofu obtained in one of the tofu factories in the Ponorogo area. The sample in this study is a sample of 10 pieces of white tofu. The method used in this research is acid-base titration followed by statistical analysis using the SPSS program. The research was conducted at the AKAFARMA Laboratory of Sunan Giri Ponorogo. Results: The results of this study showed that the initial formalin content of tofu was $0.0146 \%$ with the highest reduction in formalin content at a concentration of $60 \%$ as much as $28.0 \%$. Conclusions and suggestions: the results of the analysis show that the Temu Kunci solution can reduce formalin levels in white tofu samples. It is hoped that further research will use a more representative method.
\end{abstract}

Keywords: Tofu, Formalin, Key Match, Titration 


\section{PENDAHULUAN}

Indonesia termasuk negara yang beriklim teropis, karena terletak pada garis khatulistiwa yang secara astronomi berada antara 6 LU-11 LS dan 95 BT-141 BT. Sehingga penduduknya sebagian besar banyak yang bercocok tanam. Karena memiliki dua musim, yaitu musim penghujan dan musim kemarau, jadi dalam proses penanaman dapat diatur kapan musim tanam yang baik untuk tanaman pertanian. Salah satu tanaman yang banyak di tanam penduduk Indonesia ialah padi, jagung, ketela, sayur-sayuran, buahbuahan, kedelai, singkong dan banyak lagi.

Kedelai merupakan salah satu tanaman polong-polongan dan merupakan sumber utama protein dan minyak nabati utama di Dunia. Kedelai merupakan tanaman pangan utama terpenting setelah padi dan jagung. Peningkatan kebutuhan akan kedelai dapat dikaitkan dengan meningkatnya konsumsi masyarakat terhadap tahu dan tempe, serta untuk pasokan industri kecap (Mursidah,2005). Tahu merupakan salah satu hasil olahan kedelai yang banyak menggandung protein, sehingga kandungan protein dalam tahu dapat mengantikan kebutuhan protein hewani. Kandungan protein dalam tahu, memang masih kalah dibandingkan lauk pauk hewani, seperti telur, daging dan ikan. Namun, dengan harga yang lebih murah, masyarakat cenderung lebih memilih mengkonsumsi tahu sebagai bahan makanan pengganti protein hewani untuk memenuhi kebutuhan gizi.

Tahu dapat bertahan selama kurang lebih tiga hari dalam suhu kamar yaitu $25^{\circ} \mathrm{C}-$ $30^{\circ} \mathrm{C}$ dan tanpa menggunakan bahan pengawet. Bahan dasar tahu sendiri yaitu kedelai, air, dan bahan penggumpal. Dari bahan dasar tersebut tahu banyak mengandung protein dan air hal ini menyebabkan tahu menjadi media yang cocok untuk tumbuhnya mikroba, sehingga tahu dapat cepat mengalami kerusakan. Karena tahu mudah rusak maka ada beberapa produsen menggunakan bahan pengawet kimia guna memperpanjang daya simpan dan untuk menghambat kerusakan pada tahu. Salah satu bahan pengawet yang sering digunakan yaitu bahan pengawet kimia formalin. Hal ini dikarenakan harga formalin jauh lebih murah dan mudah digunakan karena berbentuk larutan dibandingkan bahan pengawet lain (Krisnawati,2018).

Penggunaan formalin belum disadari oleh masyarakat karena kurangnya pengetahuan dan bahaya yang ditimbulkan. Peraturan Menteri Kesehatan RI No. 1168/Menkes/Per/X/1999 menyatakan bahwa formalin adalah salah satu bahan tambahan dilarang yang dipergunakan pada makanan. Karena bahan kimia yang terkandung dalam 
formalin bersifat kersinogenik (penyebab kanker) dan mutagen (menyebabkan perubahan sel fungsi hati dan jarigan).

Berdasarkan IPCS (International Programme On Chemical Safety), lembaga khusus dari tiga organisasi di PBB, secara umum ambang batas aman formalin pada tubuh yaitu 1 $\mathrm{mg} / \mathrm{l}$. Sedangkan formalin yang diperbolehkan masuk kedalam tubuh manusia dalam bentuk makanan untuk orang dewasa yaitu 1,5 mg hingga $14 \mathrm{mg}$ per hari (Hastuti,2010). Maka berbahaya jika mengkonsumsi berlebih makanan yang mengandung formalin.

Temu kunci merupakan tanaman berbatang semu dan mempunyai rimpang berwarna kuning keputihan. Jumlah daun antara 2-7 helai dan di bagian bawah sering terlihat pelepah berwarna merah tanpa helai daun. Bunga majemuk berbentuk tandan berwarna merah jingga (Mursito, 2000). Kandung kimia yng ada dalam temu kunci yaitu minyak atsiri , saponin, flavonoid, kurkumin, sineol, kamfer, zingebirerin, d-boeneol, metal sinamat, zedoarin, hidromirsen, dammar, zat pati, pinostrolerin, serta alipinetin. Senyawa saponin inilah yang mampu mereduksi kadar formalin.

Penelitian ini bertujuan untuk mengetahui kadar formalin pada tahu putih, untuk mengetahui efektifitas larutan temu kunci dalam mereduksi formalin. Hipotesa: diduga larutan temu kunci dapat menurunkan kadar formalin pada sampel tahu putih.

\section{METODE PENELITIAN}

Penelitian ini dilakukan di Laboratorium Akafarma Sunan Giri Ponorogo pada bulan juli 2020. Populasi dalam penelitian ini adalah tahu putih yang diambil dari salah satu pabrik di Wilayah Ponorogo selama 1 kali produksi. Teknik penggumpulan data yaitu Sample Random Sampling. Sampel di uji oeganoleptis: warna, rasa dan bau, uji kualitatif: sampel ditambahkan dengan reagen Schiff, reagen asam kromatopat dan reagen fehling A dan B. Uji kuantitatif dilakukan dengan menggunakan metode titrasi asam basa dengan sampel dititrasi dengan baku sekunder $\mathrm{H}_{2} \mathrm{SO}_{4} 0,1 \mathrm{~N}$.

Alat dan Bahan: yang digunakan Sampel tahu putih Asam kromatopat 0,5\%, $\mathrm{H}_{2} \mathrm{SO}_{4} \mathrm{p}$, reagent fehling A dan B, reagent Shiff, $\mathrm{H}_{2} \mathrm{O}_{2} 3 \%$, indicator fenolftalin, $\mathrm{H}_{2} \mathrm{C}_{2} \mathrm{O}_{4} \cdot 2 \mathrm{H}_{2} \mathrm{O} 0,1 \mathrm{~N}$, $\mathrm{H}_{2} \mathrm{SO}_{4} 0,1 \mathrm{~N}$, Aquadest.

Prosedur penelitian:Pembuatan larutan induk konsentrasi $80 \%$ Temu kunci dicuci dan ditimbang sebanyak 800 gram Temu kunci dirajang dengan pisau kemudian dihaluskan dengan blender, saring dan dilarutkan dengan aquadest $1000 \mathrm{ml}$. Pembuatan larutan temu kunci 20\%, 40\%, dan 60\% Konsentrasi 20\% didapat dari larutan induk 80\% sebanyak $125 \mathrm{ml}$ 


\section{Jurnal MEDFARM: Farmasi dan Kesehatan}

Vol. 9, No.1, Januari 2020, hal 29-35

e-ISSN : 2715-9957

dan ditambahkan $500 \mathrm{ml}$ aquadest. Konsentrasi $40 \%$ didapat dari larutan induk 80\% sebanyak $250 \mathrm{ml}$ dan ditambahkan $500 \mathrm{ml}$ aquadest. Konsentrasi 60\% didapat dari larutan induk $80 \%$ sebanyak $375 \mathrm{ml}$ dan ditambahkan $500 \mathrm{ml}$ aquadest.

Prosedur uji kualitatif Sampel ditimbang 100 gram dihaluskan kemudian di destilasi, hasil destilasi diambil masing-masing $1 \mathrm{ml}$ untuk ditambahkan reagen schiff, reagen asam kromatopat, dan reagen fehling A dan B. Dengan penambahan reagen schiff akan menghasilkan warna merah muda, asam kromatopat akan membentuk warna keunguan, dan dengan fehling A dan B akan membentuk endapan merah bata jika dipanaskan.

Pengujian Formalin dengan metode titrasi asam basa Sampel ditimbang 100 gram dihaluskan kemudian di destilasi, hasil destilasi diambil 10,0 ml, ditambahkan $25 \mathrm{H}_{2} \mathrm{O}_{2}$ dan $25 \mathrm{ml} \mathrm{NaOH}$ ditetesi indikator BTB 3 tetes dititrasi dengan $\mathrm{H}_{2} \mathrm{SO}_{4} 0,1 \mathrm{~N}$. Data yang diperoleh di analisis secara statistik dengan menggunakan program SPSS ANOVA satu jalan ( one way ANOVA) untuk mengetahui adanya pengaruh larutan temu kunci dalam menurunkan kadar formalin pada sampel tahu

\section{HASIL DAN PEMBAHASAN}

Berdasarkan hasil penelitian pada uji organoleptik pada tabel 1 sampel terjadi perubahan yaitu lebih spesifik ke bau dan rasa temu kunci, ini dikarenakan adanya senyawa temu kunci yang bereaksi pada sampel. Pada uji kualitatif pada sampel tahu sebelum dan sesudah perendaman larutan temu kunci pada tabel 2 menunjukkan hasil positif mengandung formalin dengan adanya perubahan pada penambahan reagen schiff, reagen asam kromatopat, dan reagen fehling A dan B. Reagen schiff digunakan utuk menunjukkan adanya senyawa aldehid alifatik, jika sampel ditambahkan reagen schiff maka akan bereaksi dengan senyawa aldehid dan akan menghasilkan warna merah keungu. Identifikasi menggunakan reagen asam kromatopat bertujuan untuk mengikat formalin agar terlepas dari bahan, asam kromatopat akan bereaksi dengan formalin dan menghasilkan senyawa komplek yang berwarna keunguan. Reagen fehling A dan B untuk mendeteksi gula pereduksi dan aldehid.

Tabel 1. Hasil Uji Organoleptik

\begin{tabular}{lllll}
\hline Sampel & $\begin{array}{l}\text { Sebelum } \\
\text { direndam } \\
\text { Larutan } \\
\text { temu kunci }\end{array}$ & $\begin{array}{l}\text { Setelah } \\
\text { direndam } \\
\text { larutan }\end{array}$ & & \\
\hline Bau & Kedelai & $\begin{array}{l}20 \% \\
\text { Kedelai } \\
\text { campur temu } \\
\text { kunci }\end{array}$ & $\begin{array}{l}\text { Kedelai campur } \\
\text { temu kunci }\end{array}$ & $\begin{array}{l}\text { Kedelai } \\
\text { campur } \\
\text { temu kunci }\end{array}$ \\
\hline
\end{tabular}


Jurnal MEDFARM: $\boldsymbol{F}$ Means Plots

Vol. 9, No.1, Januari ‘

e-ISSN : 2715-9957

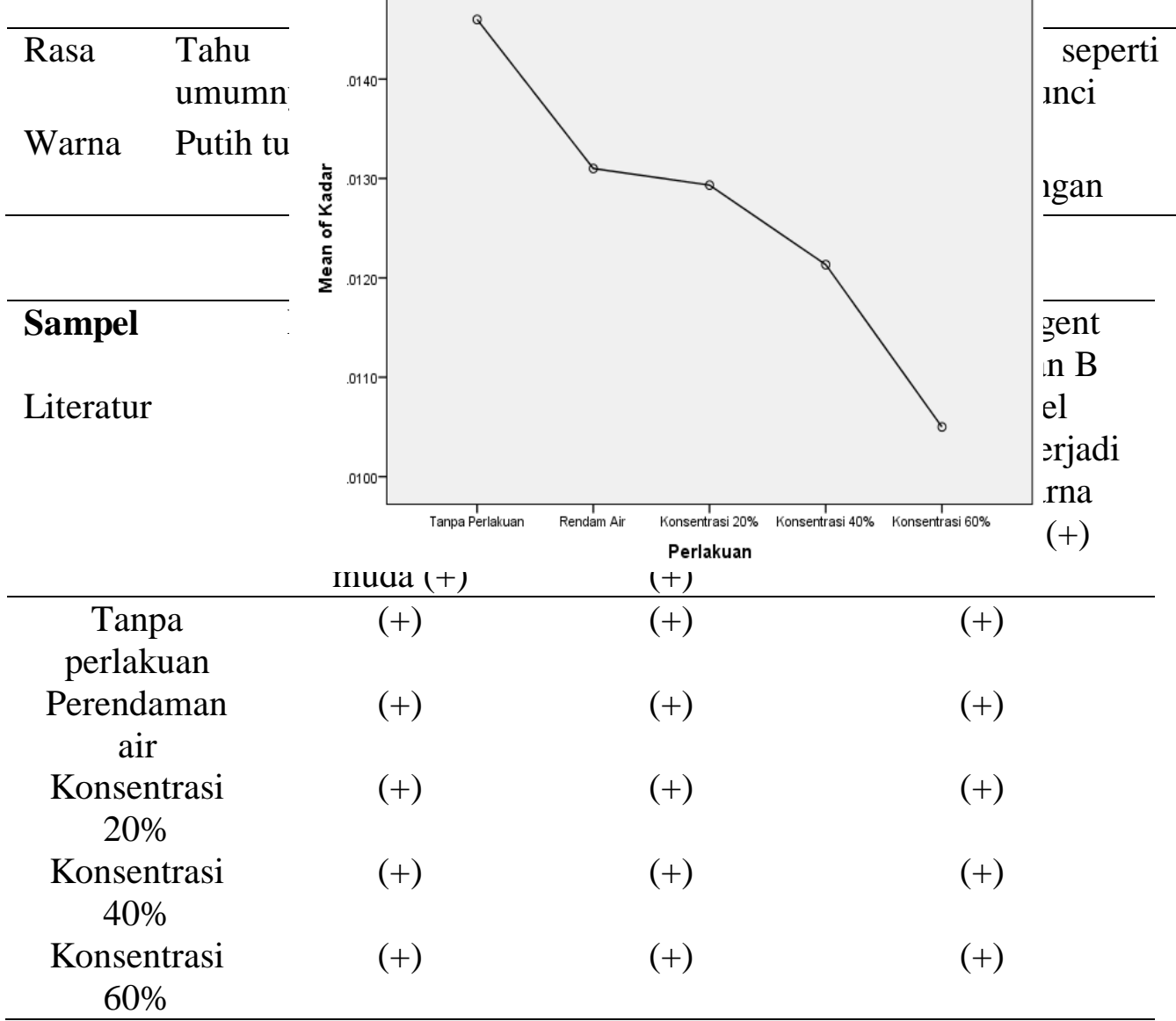

Tabel 3 hasil kadar formalin

\begin{tabular}{llll}
\hline Sampel & Kadar rata-rata $(\%)$ & $\begin{array}{l}\text { Penurunan } \\
\text { formalin }(\%)\end{array}$ & kadar \\
\hline Tanpa perlakuan & $0,0146 \%$ & $0 \%$ & \\
Direndam dengan air & $0,0131 \%$ & $10,27 \%$ & \\
Konsentrasi 20\% & $0,0129 \%$ & $13,17 \%$ & \\
Konsentrasi 40\% & $0,0120 \%$ & $17,80 \%$ & \\
Konsentrasi 60\% & $0,0105 \%$ & $28,0 \%$ & \\
\hline
\end{tabular}


Jurnal MEDFARM: Farmasi dan Kesehatan

Vol. 9, No.1, Januari 2020, hal 29-35

e-ISSN : 2715-9957

Gambar 1. diagram penurunan kadar formalin

Hasil penelitian dengan 3 sampel dan 2 kontrol sampel yang tiap sampel dilakukan pengulangan sebanyak tiga kali pada tabel 3 menunjukkan bahwa setiap penambahan temu kunci di masing-masing konsentrasi akan memberi pengaruh pada penurunan kadar formalin. Dengan penurunan kadar terkecil $13,17 \%$ konsentrasi $20 \%$ dan penurunan tertinggi konsentrasi $60 \%$ sebanya $28,0 \%$.

Dari hasil diagram diatas menunjukkan bahwa sampel dengan perendaman larutan temu kunci konsentrasi 20\%, 40\%, dan 60\% dapat menurunkan kadar formalin secara signifikan, dengan penurunan terbesar pada konsentrasi $60 \%$, ini dikarenakan semakin banyak penambahan temu kunci dalam perendaman sampel tahu putih maka akan semakin maksimal larutan temu kunci dalam menyerap formalin.

Kadar formalin pada sampel tahu putih mengalami penurunan setelah direndam larutan temu kunci di karenakan adanya reaksi antara gugus saponin dengan formalin. Karena saponin memiliki gugus surfaktan (polar serta non polar) yang mampu mengemulsi air serta formalin. Bagian gugus polar akan bereaksi dengan air sehingga formalin dapat larut dalam air.

Berdasarkan uji normalitas diperoleh nilai signifikan lebih besar dari 0,05 $(\mathrm{P}<0,05)$ yang artinya populasi berdistribusi normal, sedangkan uji homogenitas diperoleh nilai signifikan lebih dari 0,05 ( $\mathrm{P}>0,05)$ yaitu sebesar 0,944 Artinya populasi data homogen.

Sehingga dapat dilanjutkan uji statistik Anova. Berdasarkan hasil Anova diperoleh nilai signifikan kurang dari $0,05(\mathrm{P}<0,05)$ yaitu sebesar 171,127 yang artinya bahwa terdapat pengaruh temu kunci (Boesenbergia rotunda) terhadap penurunan kadar formalin pada tahu putih. Untuk mengetahui temu kunci mempunyai perbedaan bermakna atau tidak dengan air maka dilanjutkan uji statistik Post Hoc. Hasil uji lanjutan Post Hoc menunjukkan nilai singnifikansi kurang dari 0,05 sebesar 0,000 maka larutan temu kunci memiliki perbedaan yang bermakna dari air.

Berdasarkan hasil analisa data dengan menggunakan program SPSS menunjukkan hasil bahwa konsentrasi rendaman larutan temu kunci mampu menurunkan kadar formalin pada sampel tahu putih. Dengan penurunan tertinggi terdapat pada konsentrasi $60 \%$ dengan prosentase sebesar $28,0 \%$. 
Jurnal MEDFARM: Farmasi dan Kesehatan

Vol. 9, No.1, Januari 2020, hal 29-35

e-ISSN : 2715-9957

\section{A. KESIMPULAN}

Berdasarkan hasil penelitian yang telah dilakukan dapat disimpulkan sebagai berikut: Larutan temu kunci dapat menurunkan kadar formalin pada tahu putih, konsentrasi paling tinggi untuk menurunkan kadar formalin terdapat pada konsentrasi $60 \%$ dengan prosentase penurunan kadar sebesar 28,0\%

\section{DAFTAR PUSTAKA}

Elfia, Yuni. 2018. “ Analisa Kadar Formalin Pada Sediaan Cat Kuku (Kutek) Yang Diperjualbelikan Di Pasar Petisan Medan". KTI Medan. Politeknik Kesehatan Kemenkes RI Medan.

Hastuti, S. 2010. Analisis Kualitatif Dan Kuantitatif Formaldehid Pada Ikan Asin di Madura. Jurnal agrointek, 4(2), 132-137.

Krisnawati,Monik. 2018. penetapan kadar formalin pada mie basah yang dijual di pasar piyugan dengan metode spektorofometri uv-vis. jurnal kesehatan madani medika, vol 9 no 2.

Mursidah. 2005. U.P.D.P.K., Perkembangan Produksi Kedelai Nasional Dan Upaya Pengembangannya Di Propinsi Kalimantan Timur. Diakses 21 februari 2020.

Mursito, bambang. 2000. Tampil percaya diri dengan ramuan tradisional. Jakarta: penebar swadaya

Zamhariroh, Zamhariroh, and Galuh Ratmana Hanum. "Efektivitas Temu Kunci (Boesenbergia rotunda) Terhadap Penurunan Kadar Formalin Pada Ikan Tuna (Thunnus sp.)." Medicra (Journal of Medical Laboratory Science/Technology) 1.2 (2018): 68-76. 